\title{
EVALUASI PELAKSANAAN PRAKTIK KERJA INDUSTRI PESERTA DIDIK PROGRAM KEAHLIAN TEKNIK OTOMOTIF SMK GIRIPURO SUMPIUH
}

\author{
Umar Nur Arif \\ SMK Giripuro Sumpiuh \\ umarnurarif@gmail.com \\ Wardan Suyanto \\ Universitas Negeri Yogyakarta \\ wardansuyanto@uny.ac.id
}

\begin{abstract}
Abstrak
Penelitian ini bertujuan untuk mengetahui pelaksanaan Praktik Kerja Industri peserta didik Program keahlian Teknik Otomotif di SMK Giripuro Sumpiuh. Teknik pengumpulan data menggunakan angket, dokumentasi dan observasi. Data penelitian dikumpulkan melalui kuesioner yang kemudian dianalisis secara diskriptif kuantitatif. Hasil penelitian menunjukkan: (1) Konteks peserta didik menyatakan memahami sebanyak 96 siswa (80\%), guru pembimbing sekolah menyatakan memahami sebanyak 5 guru (50\%) dan pembimbing industri menyatakan memahami sebanyak 10 pembimbing $(83,4 \%)$. (2) Input persta didik menyatakan cukup siap sebanyak 58 siswa (48,3\%), guru pembimbing sekolah menyatakan siap sebanyak 6 guru (60\%) dan pembimbing industri menyatakan siap sebanyak 9 pembimbing (75\%). (3) Proses peserta didik menyatakan rajin sebanyak 82 siswa (68,3\%), guru pembimbing sekolah menyatakan rajin dan kurang rajin berimbang sebanyak 5 guru pembimbing (50\%) dan pembimbing industri menyatakan rajin sebayak 11 pembimbing (91,7\%). (4) Produk peserta didik menyatakan baik sebanyak 87 siswa $(72,5 \%)$.
\end{abstract}

Kata Kunci: Praktik Kerja Industri, Keahlian Teknik Otomotif

\section{EVALUATION OF WORK PRACTICE OF AUTOMOTIVE ENGINEERING PROGRAM VOCATIONAL HIGH SCHOOL GIRIPURO SUMPIUH}

\begin{abstract}
This study aims to determine the implementation of the Industrial Employment Practices of Automotive Engineering Program learner in Vocational school Giripuro Sumpiuh. Techniques of data collection using questionnaires, documentation and observation. Data were collected through a questionnaire which was then analyzed by descriptive quantitative. The results of the study as follows: (1) learner context showed students understand as many as 96 (80\%), school counselor show understanding by 5 teachers (50\%) and industry mentors demonstrate understanding by 10 counselors $(83.4 \%)$. (2) Students input showed quite ready by 58 students (48.3\%), school counselor stated ready by 6 teachers $(60 \%)$ and industry mentors show ready by 9 tutors (75\%). (3) The process stated diligent learners showed as many as 82 students (68.3\%), school counselor showed less diligent and impartial guidance counselor as much as $5(50 \%)$ and industry mentors demonstrate diligent supervisor as many as 11 (91.7\%). (4) The product showed good learners as many as 87 students (72.5\%).
\end{abstract}

Keywords: Employment Practices Industry, Automotive Engineering Expertis 


\section{PENDAHULUAN}

Bangsa Indonesia merupakan bagian dari masyarakat dunia tidak dapat menghindar dari konsekuensi era globalisasi. Keunggulan kompetitif yang selama ini dimiliki, seperti tenaga (buruh) yang murah, tersedianya bahan alam, kemudahan berinvestasi di Indonesia tidak lagi relevan untuk dijadikan andalan.

Salah satu kebijakan penting di bidang pendidikan kejuruan menjelang era globalisasi tahun 2020 adalah tentang Praktik Kerja Industri. Kebijakan tersebut dilatar belakangi oleh rendahnya mutu tamatan SMK dan makin besarnya tantangan yang dihadapi bangsa Indonesia dalam persaingan global. Di masa yang akan datang bangsa Indonesia harus mampu mengelola dan mengembangkan berbagai sumber daya yang ada termasuk sumber daya manusianya.

Salah satu cara meningkatkan kualitas sumber daya manusia Indonesia adalah dengan meningkatkan kualitas tamatan SMK melalui pelaksanaan Praktik Kerja Industri. Dengan demikian sesuai dengan tuntutan dunia kerja memasuki dunia kerja peserta didik harus memiliki kecakapan hidup berjiwa wirausaha terutama bagi satuan pendidikan kejuruan dan peserta didik yang tidak melanjutkan ke jenjang yang lebih tinggi (BNSP 2006).

Praktik Kerja Industri merupakan kurikulum wajib bagi peserta didik SMK untuk melakukan kerja di Dunia Usaha atau Dunia Industri (DU/DI) yang sesuai dengan program keahlian yang bersangkutan. Pelaksanaan Praktik Kerja Industri yang merupakan inovasi pada program SMK dimana peserta didik melakukan Praktik kerja (magang) di perusahaan atau industri yang merupakan bagian integral dari proses pendidikan dan pelatihan di SMK.

Waktu pelaksanaan Praktik Kerja Industri berdasarkan kurikulum SMK edisi 2006 diatur sebagai berikut:

1. Minimum 3 bulan kerja, mengikuti minggu dan jam kerja industri

2. Boleh lebih dari 3 bulan kerja, jika kegiatan bekerja di industri memiliki nilai tambah yang lebih tinggi bagi industri maupun bagi Peserta didik yang bersangkutan.
3. Kegiatan di industri dapat dimulai dari tingkat 1 dengan catatan industri yang bersangkutan mampu memberi ketrampilan dasar dan sebaiknya tidak langsung bekerja di lini produksi.

Hasil dari Praktik Kerja Industri ini diharapkan dapat memberikan bekal nyata kepada Peserta didik agar dapat mengaplikasikan apa yang telah didapat di sekolah dan secara langsung mereka dapat mengerjakan sesuai dengan kondisi yang sebenarnya di industri, sehingga begitu dinyatakan lulus dari sekolah kejuruan minimal siap latih untuk bekerja ataupun mempunyai bekal skill yang dapat dikembangkan dalam dunia wirausaha.

Jika Praktik Kerja Industri berjalan sesuai dengan tujuan yang ditetapkan maka akan berpengaruh penciptaan lapangan kerja dan mengurangi angka pengangguran. Rainer (1992: 59) menyatakan "The dual system has proved its success, as is shown by its ability to react quickly and effectively to the many changes in the economy and in Society, and the fact that youth unemployment is low". Banyaknya pengangguran dipengaruhi oleh kualitas sumber daya manusia sedangkan kualitas sumber daya manusia dipengaruhi oleh sistem pendidikannya. Pada Praktik Kerja Industri Peserta didik mandapatkan pengetahuan yang cukup di sekolah dan mendapatkan keterampilan yang cukup dari industri.

Di perusahaan yang sudah maju Praktik kerja industri dilaksanakan dengan menerapkan peserta Praktik sama dengan karyawan sendiri. Seperti yang dikemukakan Nolker (1983: 112): "segi positif pendidikan yang dilaksanakan di pabrik adalah pendidikan berlangsung dekat dengan kenyataan Praktik, pendidikan dengan cepat dapat disesuaikan dengan persyaratan baru yang timbul dalam pasaran kerja, dan biaya pendidikan lebih rendah dibandingkan dengan biaya dalam lembaga lain karena peserta didik ikut bekerja"

Keuntungan Praktik industri bagi sekolah adalah membantu terselenggaranya pendidikan karena keterbatasan sarana prasarana yang dimiliki sekolah, efektifitas kerja. Keuntungan bagi industri dengan adanya Peserta didik yang Praktik di industri tersebut adalah adanya tenaga kerja baru yang dapat dimanfaatkan oleh pe- 
rusahaan. Adanya pelatihan yang lebih dini sehingga dapat dijadikan pionir untuk perekrutan tenaga kerja sehingga meningkatkan efektifitas recruitment dan dapat memilih calon tenaga kerja yang mempunyai kualitas tinggi.

Sudah menjadi masalah klasik bagi dunia pendidikan SMK di Indonesia pada umumnya, bahwa link and match antara output pendidikan SMK dengan dunia usaha/dunia industri (DU/DI)sebagai pengguna output pendidikan SMK belum tercapai. Salah satu masalahnya terletak pada kualiatas lulusan SMK yang belum sesuai dengan standar kemampuan yang dibutuhkan pasar tenaga kerja. Berbagai usaha telah dilakukan namun hingga kini pelaksanaan Praktik Kerja Industri masih belum optimal manfaatnya karena banyak kendala yang dihadapi di lapangan.

Menurut Donaldson (1993: 16) ada enam masalah pokok yang cenderung menghambat keberhasilan program pelatihan yaitu:

1. Pelatihan tidak dimaksudkan untuk mengacu pada tujuan yang spesifik.

2. Tujuan program pelatihan tidak diidentifikasikan dengan jelas.

3. Instruktur tidak dipersiapkan atau materi tidak sesuai dengan tujuan pelatihan.

4. Peserta pelatihan tidak berminat mengikuti program.

5. Tidak ada ketentuan untuk mengevaluasi hasil hasil pelatihan.

Sumber kendala dalam pelaksanaan Praktik Kerja Industri adalah terbatasnya jumlah industri yang bersedia sebagai tempat Praktik kerja, begitu pula kendala yang bersumber dari sekolah. Diantaranya adalah kurangnya perhatian guru pembimbing terhadap peserta didik, motivasi peserta didik untuk belajar di industri rendah, pemahaman guru pembimbing tentang industri kurang, dan monitoring ke industri kurang.Banyaknya kendala yang dihadapi dalam pelaksanaan Praktik Kerja Industri menyebabkan tujuan tidak tercapai bahkan dampak negatifnya terbawa ke sekolah setelah peserta didik masuk mengikuti pelajaran semester berikutnya. Dampak negatif tersebut antara lain : peserta didik tidak disiplin, tidak sopan, dan motivasi belajarnya rendah serta rambut panjang dan disemir setelah praktik industri.
Adapun tujuan dari penelitian ini adalah untuk mengevaluasi pelaksanaan Praktik Kerja Industri di SMK Giripuro Sumpiuh yang meliputi evaluasi konteks, evaluasi masukan, evaluasi proses dan evaluasi hasil.

Dari penelitian ini diharapkan dapat memberikan gambaran tentang pelaksanaan Praktik Kerja Industri di SMK dan sebagai bahan evaluasi untuk pelaksanaan Praktik industri, hal ini dikarenakan pelaksanaan Praktik Kerja Industri merupakan hal yang sangat urgen di sekolah kejuruan sehingga perlu untuk diadakan suatu penelitian guna perbaikan dan sebagai pertimbangan bagi pejabat yang berwenang untuk pengambilan kebijakan.

\section{METODE PENELITIAN}

\section{Jenis Penelitian}

Berdasarkan permasalahan penelitian CIPP maka penelitian ini menggunakan pendekatan evaluasi dengan analisis deskriptif kuantitatif, yaitu penelitian untuk mengetahui pelaksanaan suatu program. Dalam tesis ini merupakan penelitian evalusi dari kebijakan pelaksanaan program pendidikan untuk mengetahui pelaksanaan Praktik Kerja Industri peserta didik program keahlian teknik otomotif SMK Giripuro Sumpiuh tahun pembelajaran 2011/2012.

\section{Waktu dan Tempat Penelitian}

Tempat penelitian ini dilaksanakan di SMK Giripuro Sumpiuh Jalan Giri Tomo no 15 Sumpiuh, Kabupaten Banyumas, Jawa Tengah selama tiga bulan mulai awal September 2012 sampai dengan bulan Desember 2012.

\section{Target/Subjek Penelitian}

Sasaran yang dicermati dalam penelitian ini mengarah pada (1) Context evaluation yaitu evaluasi tentang Konteks. (2) Input evaluation yaitu evaluasi tentang masukan. (3) Process evaluation yaitu evaluasi tentang proses dan, (4) Product evaluation yaitu evaluasi tentang produk atau hasil yang diambil dari subyek penelitian yaitu seluruh pihak yang terkait dengan pelaksaan Praktik Kerja Industri peserta didik program keahlian teknik otomotif SMK Giripuro Sumpiuh, baik guru pembimbing, 
peserta didik dan pembimbing industri sebagai narasumber atau sumber informasi yang dapat memberikan berbagai informasi yang terkait dengan tujuan penelitian tersebut.

Sumber informasi atau narasumber yang dijadikan sebagai obyek sekaligus subyek penelitian yaitu:

1. Guru pembimbing sekolah yaitu para guru produktif pengampu program keahlian teknik otomotif dalam hal ini akan diungkap tentang bagaimana pemahaman tujuan dan manfaat Praktik Kerja Industri, kesiapan guru pembimbing yang meliputi latar belakang pendidikan, motivasi dan administrasi, tugas guru pembimbing meliputi metode bimbingan, frekuensi bimbingan, pengarahan dan hambatan. Keseluruhan guru pembimbing sekolah yang dijadikan sumber informasi berjumlah 10 orang.

2. Peserta didik yaitu peserta yang melaksanakan program Praktik Kerja Industri program keahlian teknik otomotif kelas sebelas Tahun Pembelajaran 2011/2012 SMK Giripuro Sumpiuh, dalam hal ini akan diungkap tentang bagaimana pemahaman peserta didik terhadap tujuan dan manfaat Praktik Kerja Industri, kesiapan peserta didik meliputi: kemampuan tentang teknik otomotif, pengalaman Praktik teknik otomotif, administrasi, kegiatan peserta didik meliputi : disiplin kerja, keterlibatan dalam Praktik dan pembimbingan dari pembimbing industri. Keseluruhan peserta yang dijadikan sebagai sumber informasi berjumlah 120 orang.

3. Pembimbing industri yaitu pembimbing yang terlibat langsung dengan peserta didik pada saat pelaksanaan Praktik Kerja Industri di Industri, dalam hal ini akan diungkap bagaimana pemahaman terhadap tujuan dan manfaat Praktik Kerja Industri, kesiapan pembimbing industri meliputi latar belakang pendidikan, pengalaman kerja dan motivasi,tugas pembimbing industri meliputi perangkat untuk membimbing, bimbingan kepada peserta didik dan penilaian kepada peserta didik. Keseluruhan pembimbing industri yang dijadikan sumber informasi berjumlah 12 orang.

\section{Tehnik Pengumpulan Data}

Teknik pengumpulan data yaitu cara yang dipergunakan untuk mengumpulkan data yang diperlukan dalam penelitian. Teknik pengumpul data yang dipergunakan dalam penelitian ini adalah:

\section{Angket}

Angket sebagai alat pengumpul data berupa lembaran yang berisi pertanyaan-pertanyaan yang harus dijawab atau diisi oleh responden, bentuk pertanyaan ini adalah questioner tertutup sehingga responden hanya menjawab pada jawaban yang telah disediakan.

\section{Dokumentasi}

Dokumentasi dipergunakan untuk mengetahui data tentang data tertulis yang ada di sekolah dan dokumen dari industri. Data dokumentasi ini penulis peroleh dari data yang ada pada bagian Praktik kerja industri berupa nama peserta didik, tempat Praktik, lamanya Praktik dan alamat Praktik peserta didik nilai hasil prakerin, foto kegiatan saat di industri.

\section{Observasi}

Teknik observasi digunakan untuk melihat langsung pelaksanaan praktik kerja industri di industri tempat peserta didik melaksanakan praktik kerja industri.

\section{Wawancara}

Yaitu proses tanya jawab cara mendalam dengan peserta didik peserta prakerin, pembimbing industri dan guru produktif pembimbing praktik kerja industri.

Teknik pengukuran data yang dipergunakan pada angket menggunakan penilaian secara berjenjang. Untuk setiap item konteks, input, proses dan produk diberiakan beberapa alternatif jawaban yang sesuai dengan keadaan obyek penelitian. Mengingat keberhasilan penelitian ini dapat ditentukan oleh pengumpulan data yang baik, yang diperoleh dari instrumen yang valid dan reliabel. Langkah-langkah untuk mendapatkan data yang valid sebagai berikut:

Langkah persiapan

Kegiatan yang dilakukan dalam langkah persiapan ini yaitu mengadakan spesifikasi 
data dan sumber dari data. Spesifikasi yang dimaksud disesuaikan dengan lingkup masalah dan tujuan dari penelitian yang hendak dicapai.

\section{Langkah perencanaan}

Langkah perencanaan digunakan untuk menentukan jumlah item pada setiap angket dan alteraatif jawabannya serta cara yang dipergunakan untuk mengolah data yang diperoleh. Oleh sebab itu harus dibuat kisi-kisi angket dari setiap variabel penelitian dan kemudian dijabarkan menjadi beberapa indikator, dari indikator tersebut dijabarkan dalam bentuk pernyataan, pertanyaan atau isian yang terwakili melalui item-item merupakan instrumen penelitian.

\section{Langkah penyusunan}

Item-item disusun berdasarkan kisi-kisi angket, yang selanjutnya disusun dalarn bentuk soal yang telah ditentukan, kemudian dicocokan, diteliti dan dipersiapkan untuk diujicobakan.

\section{Langkah uji coba instrumen (try out)}

Sebelum angket di pergunakan untuk penelitian yang sesungguhnya, maka terlebih dahulu diuji coba. Hal ini dimaksudkan untuk:

- Menghindari pernyataan atau pertanyaan yang kurang jelas.

- Menghindari adanya kata-kata yang sulit untuk dimengerti.

- Menambah atau menghilangkan item-item yang kurang mengena, tidak terjawab oleh para responden.

- Melihat tingkat validitas dan reliabilitas dari angket yang dibuat.

Langkah Penyebaran Angket

Penelitian di sekolah menengah kejuruan (SMK) Giripuro Sumpiuh Kabupaten Banyumas dilakukan terhadap peserta didik dengan jumlah peserta didik 120 peserta, guru pembimbing sejumlah 10 dan pembimbing industri sejumlah 12 orang.

\section{Langkah pengolahan}

Setelah dijawab oleh responden, maka angket dikumpulkan, disekor dan ditabulasi sesuai dengan masing-masing komponen. Kemudian dari data tersebut dilakukan penghitungan atau penganalisisan data.

\section{Teknik Analisis Data}

Penelitian ini adalah termasuk penelitian deskriptif kuantitatif dengan metode survey, maksudnya hasil dari penelitian ini nantinya adalah memotret dan menggambarkan pelaksanaan Praktik Kerja Industri peserta didik Program Keahlian Teknik Otomotif SMK Giripuro Sumpiuh Kabupaten Banyumas sementara ini sedang atau telah berjalan. Teknik analisa data yang digunakan adalah dengan pemakaian tabel frekuensi, Persentasi harga rerata dengan menggunakan rumus :

$$
\mathrm{P}=\mathrm{f} / \mathrm{N} \times 100 \%
$$

Keterangan:

$$
\begin{aligned}
& \mathrm{P}=\text { Prosentase yang dicari } \\
& \mathrm{f}=\text { Jumlah jawaban responden } \\
& \mathrm{N}=\text { Jumlah sampel (Arikunto, 1988) }
\end{aligned}
$$

Untuk membuat daftar distribusi frekuensi dengan panjang kelas yang sama, maka dilakukan beberapa langkah di bawah ini (Sudjana, 1992 : 47-48):

1. Tentukan rentang, yaitu data terbesar dikurangi data terkecil.

2. Tentukan banyak kelas interval.

3. Tentukan panjang kelas interval yaitu dengan menggunakan rumus :

$$
\text { int erval }=\frac{\text { ren } \tan g}{\text { banyak kelas }}
$$

Pilih ujung bawah kelas interval pertama, untuk hal ini bisa diambil sama dengan data terkecil atau nilai data yang lebih kecil dari data terkecil, tetapi selisihnya harus kurang dari panjang kelas yang telah ditentukan.

\section{HASIL PENELITIAN DAN PEMBAHASAN}

Data hasil penelitian yang didapatkan kemudian dianalisis menggunakan statistik deskripsi, meliputi: (1) pemahaman terhadap tujuan, manfaat praktik kerja industri, tempat kesiapan, kegiatan peserta didik di industri dan hasil praktik kerja industri peserta didik SMK Giripuro Sumpiuh Kabupaten Banyumas; (2) Pemahaman tujuan, manfaat praktik kerja industri, tugas pembimbing, kesiapan guru pem- 
bimbing dan pelaksanaan tugas guru pembimbing sekolah dalam membimbing kerja praktek industri di SMK Giripuro Sumpiuh Kabupaten Banyumas; (3) Pemahaman tujuan, manfaat praktik kerja industri, tugas pembimbing, kesiapan guru pembimbing dan pelaksanaan tugas pembimbing industri dalam membimbing kerja praktek industri di SMK Giripuro Sumpiuh Kabupaten Banyumas.

Pembahasan evaluasi praktik kerja industri program keahlian teknik otomotif di SMK Giripuro Sumpiuh Kabupaten Banyumas meliputi komponen konteks, input, proses dan produk. Faktor yang mempengaruhi keberhasilan praktik kerja industri peserta didik ada dua yaitu faktor intern dan ekstern. Faktor intern merupakan faktor yang berasal dari dalam diri peserta didik yaitu pemahaman tentang tujuan, manfat dan tempat kerja praktik industri, kesiapan dalam melaksanakan keja praktik industri dan kerajinan peserta didik dalam mengikuti kerja praktik industri. Faktor eksternal merupakan faktor yang berasal dari luar diri siswa, yang meliputi pemahaman pembimbing sekolah dan industri terhadap tujuan, manfaat dan tugas sebagai pembimbing, kesiapan pembimbing sekolah dan pembimbing industri dalam pemberikan bimbingan kerja praktik industri dan pelaksanaan tugas pembimbing sekolah dan industri dalam memberikan bimbingan kerja praktik industri.

\section{Evaluasi Konteks}

Tabel 1. Persentasi Distribusi Ketercapaian Indikator Pada Variabel Konteks Peserta Didik

\begin{tabular}{clcc}
\hline $\begin{array}{c}\text { Interval } \\
\text { Nilai }\end{array}$ & Kriteria & Hasil & Persentasi \\
\hline $0-280$ & Kurang paham & 3 & 2,5 \\
$281-560$ & Cukup paham & 21 & 17,5 \\
$561-840$ & Paham & 96 & 80 \\
\hline
\end{tabular}

Tabel 2. Persentasi Distribusi Ketercapaian Indikator Pada Variabel Konteks Guru Pembimbing Sekolah

\begin{tabular}{clcc}
\hline $\begin{array}{c}\text { Interval } \\
\text { Nilai }\end{array}$ & Kriteria & Frekuensi & Persentasi \\
\hline $0-30$ & Kurang paham & 4 & 40 \\
$31-60$ & Cukup paham & 1 & 10 \\
$61-90$ & Paham & 5 & 50 \\
\hline
\end{tabular}

Tabel 3. Persentasi Distribusi Ketercapaian Indikator Pada Variabel Konteks Pembimbing Industri

\begin{tabular}{clcc}
\hline $\begin{array}{c}\text { Interval } \\
\text { Nilai }\end{array}$ & Kriteria & Frekuensi & Persentasi \\
\hline $0-32$ & Kurang paham & 1 & 8,3 \\
$33-66$ & Cukup paham & 1 & 8,3 \\
$67-96$ & Paham & 10 & 83,4 \\
\hline
\end{tabular}

Merupakan pemahaman praktik kerja industri sebelum melakukan kerja praktik industri oleh peserta didik peserta praktik kerja industri, pembimbing sekolah dan pembimbing industri. Hasil dari evaluasi konteks peserta didik peserta praktik kerja industri terbanyak adalah dalam kategori paham sebanyak 80 peserta didik (96\%), evaluasi konteks pembimbing sekolah yang menjadi pembimbing praktik kerja industri terbanyak dalam kategori paham sebanyak 5 guru pembimbing sekolah $(50 \%)$ dan evaluasi konteks pembimbing industri yang menjadi pembimbing kerja praktik industri terbanyak dalam kategori paham sebanyak 10 pembimbing industri $(83,4)$. Sehingga secara umum variabel konteks untuk menunjang keberhasilan peserta didik dalam mengikuti kerja praktik industri adalah paham. Hasil evaluasi konteks dilihat dari Persentasi yang paling rendah adalah Persentasi tingkat pemahaman guru pembimbing sekolah dalam memahami tujuan, manfaat dan tugas dari pembimbing sekolah memberikan bimbingan kerja praktik industri kepada peserta didik sebanyak 50\%. Sehingga pembimbing sekolah yang akan menjadi pembimbing kerja praktik industri perlu meningkatkan pemahaman tentang tujuan, manfaat dan tugas dari pembimbing sekolah. Variabel konteks pembimbing sekolah merupakan salah satu faktor eksternal yang dapat meningkatkan keberhasilan peserta didik dalam mengikuti kerja praktik industri.

\section{Evaluasi Input}

Tabel 4. Persentasi Distribusi Ketercapaian IndikatorPada Variabel Input Peserta Didik

\begin{tabular}{clcc}
\hline $\begin{array}{c}\text { Interval } \\
\text { Nilai }\end{array}$ & Kriteria & Frekuensi & Persentasi \\
\hline $0-440$ & Kurang Siap & 33 & 27,5 \\
$441-880$ & Cukup Siap & 52 & 43,3 \\
$880-1320$ & Siap & 35 & 29,2 \\
\hline
\end{tabular}


Tabel 5. Persentasi Distribusi Ketercapaian Indikator Pada Variabel Input Guru Pembimbing Sekolah

\begin{tabular}{clcc}
\hline $\begin{array}{c}\text { Interval } \\
\text { Nilai }\end{array}$ & Kriteria & Frekuensi & Persentasi \\
\hline $0-20$ & Kurang Siap & 2 & 20 \\
$21-40$ & Cukup Siap & 2 & 20 \\
$41-60$ & Siap & 6 & 60 \\
\hline
\end{tabular}

Tabel 6. Persentasi Distribusi Ketercapaian Indikator Pada Variabel Input Pembimbing Industri

\begin{tabular}{clcc}
\hline $\begin{array}{c}\text { Interval } \\
\text { Nilai }\end{array}$ & Kriteria & Frekuensi & Persentasi \\
\hline $0-32$ & Kurang Siap & 1 & 8,3 \\
$33-66$ & Cukup Siap & 2 & 16,7 \\
$67-96$ & Siap & 9 & 75 \\
\hline
\end{tabular}

Merupakan kesiapan sebelum melakukan kerja praktik industri oleh peserta didik peserta praktik kerja industri, pembimbing sekolah dan pembimbing industri. Hasil dari evaluasi input peserta didik peserta praktik kerja industri terbanyak adalah dalam kategori cukup siap sebanyak 52 peserta didik (43,3\%), evaluasi input pembimbing sekolah yang menjadi pembimbing praktik kerja industri terbanyak dalam kategori siap sebanyak 6 guru pembimbing sekolah $(60 \%)$ dan evaluasi konteks pembimbing industri yang menjadi pembimbing kerja praktik industri terbanyak dalam kategori siap sebanyak 9 pembimbing industri (75\%). Sehingga secara umum variabel konteks guru pembimbing sekolah dan pembimbing industri yang merupakan faktor eksternal untuk menunjang keberhasilan peserta didik dalam mengikuti kerja praktik industri adalah paham. Variabel konteks peserta didik yang mengikuti kerja praktik industri yang merupakan faktor internal untuk menunjang keberhasilan peserta didik dalam mengikuti kerja praktik industri adalah cukup siap. Variabel konteks peserta didik dalam kategori cukup siap, sehingga diharapkan peserta didik dapat meningkatkan pemahaman teori, pengalaman praktik dan administrasi untuk menunjang keberhasilan peserta didik dalam mengikuti kerja praktik industri.

\section{Evaluasi Proses}

Tabel 7. Persentasi Distribusi Ketercapaian Indikator Pada Variabel Proses Peserta Didik

\begin{tabular}{cccc}
\hline $\begin{array}{c}\text { Interval } \\
\text { Nilai }\end{array}$ & Kriteria & Frekuensi & Persentasi \\
\hline $0-440$ & Kurang Rajin & 11 & 9,2 \\
$441-880$ & Cukup Rajin & 27 & 22,5 \\
$880-1320$ & Rajin & 82 & 68,3 \\
\hline
\end{tabular}

Tabel 8. Persentasi Distribusi Ketercapaian Indikator Pada Variabel Proses Guru Pembimbing Sekolah

\begin{tabular}{clcc}
\hline $\begin{array}{c}\text { Interval } \\
\text { Nilai }\end{array}$ & Kriteria & Frekuensi & Persentasi \\
\hline $0-23$ & Kurang Rajin & 5 & 50 \\
$24-46$ & Cukup Rajin & 0 & 0 \\
$47-70$ & Rajin & 5 & 50 \\
\hline
\end{tabular}

Tabel 9. Persentasi Distribusi Ketercapaian Indikator Pada Variabel Proses Pembimbing Industri

\begin{tabular}{clcc}
\hline $\begin{array}{c}\text { Interval } \\
\text { Nilai }\end{array}$ & Kriteria & Frekuensi & Persentasi \\
\hline $0-32$ & Kurang Rajin & 0 & 0 \\
$33-66$ & Cukup Rajin & 1 & 8,3 \\
$67-96$ & Rajin & 11 & 91,7 \\
\hline
\end{tabular}

Merupakan kegiatan selama melakukan kerja praktik industri oleh peserta didik peserta praktik kerja industri, pembimbing sekolah dan pembimbing industri. Hasil dari evaluasi proses peserta didik peserta praktik kerja industri terbanyak adalah dalam kategori rajin sebanyak 82 peserta didik (68,3\%), evaluasi proses pembimbing sekolah yang menjadi pembimbing praktik kerja industri antara kategori kurang rajin dan rajin jumlahnya berimbang yaitu masing-masing 5 pembimbing sekolah (50\%) dan evaluasi konteks pembimbing industri yang menjadi pembimbing kerja praktik industri terbanyak dalam kategori rajin sebanyak 11 pembimbing industri $(91,7 \%)$. Sehingga secara umum variabel konteks peserta didik peserta praktik kerja industri, pembimbing sekolah dan pembimbing industri dalam kategori rajin. Variabel konteks Persentasinilai rajin yang paling rendah adalah pada kon- 
teks guru pembimbing sekolah. Pembimbing sekolah perlu meningkatkan kerajinan dalam metode pembimbingan, monitoring ke peserta didik dan evaluasi yang merupakan faktor eksternal yang dapat menunjang keberhasilan kerja praktik industri di SMK Giripuro Sumpiuh Kabupaten Banyumas.

\section{Evaluasi Produk}

Tabel 10. Persentasi Distribusi Ketercapaian Indikator Pada Variabel Produk Peserta Didik

\begin{tabular}{clcc}
\hline $\begin{array}{c}\text { Interval } \\
\text { Nilai }\end{array}$ & Kriteria & Frekuensi & Persentasi \\
\hline$<70$ & Kurang Baik & 7 & 5,8 \\
$70-80$ & Cukup Baik & 26 & 21,7 \\
$>80$ & Baik & 87 & 72,5 \\
\hline
\end{tabular}

Merupakan hasil kerja praktik industri oleh peserta didik peserta praktik kerja industri. Hasil dari evaluasi produk peserta didik peserta praktik kerja industri terbanyak adalah dalam kategori baik sebanyak 87 peserta didik (72\%). Sehingga secara umum variabel produk peserta didik peserta praktik kerja industri di SMK Giripuro Sumpiuh Kabupaten Bayumas Tahun ajaran 2011/2012 adalah berhasil dengan baik. Penilaian evaluasi produk peserta didik peserta praktik kerja industri dinilai dari hasil yang baik dalam meningkatkan keterampilan peserta kerja praktik industri, meningkatkan semangat dan etos kerja dan merasa puas setelah selesai kerja praktik industri.

\section{SIMPULAN DAN SARAN}

\section{Simpulan}

Dari hasil penelitian dan pembahasan maka dapat ditarik kesimpulan sebagai berikut:

1. Hasil evaluasi konteks pemahaman peserta didik mengenai tujuan, manfaat praktik kerja industri program keahlian teknik otomotif SMK Giripuro Sumpiuh Kabupaten Banyumas sebagian besar peserta didik dalam kategori paham sebanyak 96 peserta didik (80\%). Hasil evaluasi kontek pemahaman guru pembimbing sekolah mengenai tujuan dan manfaat praktik kerja industri program keahlian teknik otomotif SMK Giripuro Sumpiuh Kabupaten
Banyumas sebagian besar guru pembimbing sekolah dalam kategori paham sebanyak 5 guru pembimbing sekolah (50\%). Hasil evaluasi kontek pemahaman pembimbing industri mengenai tujuan dan manfaat praktik kerja industri program keahlian teknik otomotif SMK Giripuro Sumpiuh Kabupaten Banyumas sebagian besar pembimbing industri dalam kategori paham sebanyak 10 pembimbing industri $(83,4 \%)$.

2. Hasil evaluasi input mengenai kesiapan peserta didik program keahlian teknik otomotif SMK Giripuro Sumpiuh Kabupaten Banyumas sebagian besar peserta didik dalam kategori cukup siap sebanyak 58 peserta didik (48,3\%). Hasil evaluasi input mengenai kesiapan guru pembimbing sekolah dalam melaksanakan tugas membimbing peserta didik praktik kerja industri program keahlian teknik otomotif SMK Giripuro Sumpiuh Kabupaten Banyumas sebagian besar guru pembimbing sekolah dalam kategori siap sebanyak 6 guru pembimbing sekolah (60\%). Hasil evaluasi input mengenai kesiapan guru pembimbing industri dalam melaksanakan tugas membimbing peserta didik praktik kerja industri program keahlian teknik otomotif SMK Giripuro Sumpiuh Kabupaten Banyumas sebagian besar guru pembimbing industri dalam kategori siap sebanyak 9 pembimbing industri $(75 \%)$.

3. Hasil evaluasi proses mengenai kegiatan peserta didik program keahlian teknik otomotif SMK Giripuro Sumpiuh Kabupaten Banyumas sebagian besar peserta didik dalam kategori rajin sebanyak 82 siswa $(68,3 \%)$. Hasil evaluasi proses mengenai pelaksanaan tugas guru pembimbing sekolah dalam melaksanakan tugas membimbing peserta didik praktik kerja industri program keahlian teknik otomotif SMK Giripuro Sumpiuh Kabupaten Banyumas berimbang antara kategori rajin dan kurang rajin yaitu masing-masing 5 orang guru pembimbing sekolah $(50 \%)$. Hasil evaluasi proses mengenai pelaksanaan tugas pembimbing industri dalam melaksanakan tugas membimbing peserta didik praktik kerja industri program keahl- 
ian teknik otomotif SMK Giripuro Sumpiuh Kabupaten Banyumas sebagian besar pembimbing industri dalam kategori rajin sebanyak 11 pembimbing industri $(91,7 \%)$.

4. Hasil evaluasi produk mengenai peningkatan keahlian dan etos kerja setelah praktik kerja industri peserta didik program keahlian teknik otomotif SMK Giripuro Sumpiuh Kabupaten Banyumas sebagian besar dalam kategori baik sebanyak 87 peserta $\operatorname{didik}(72,5 \%)$.

\section{Saran}

Untuk meningkatkan proses bimbingan dan monitoring oleh guru pembimbing sekolah dan industri maka perlu penambahan fasilitas yang memadai untuk menunjang pelaksanaan tugas guru pembimbing sekolah dan industri.

Pihak sekolah perlu memberi perhatian lebih serius dan penghargaan kepada pembimbing industri.

\section{DAFTAR PUSTAKA}

Buntarto. (2006). Efektifitas pelaksanaan praktik kerja industri program keahlian teknik mekanik otomotif SMK di Bantul. Yogyakarta : UNY.

Carslon \& Sulvian JF. (1999), Hand on enginering, learning by doing integrated teaching and learning program. Colorado : University of Colorado Boulder

Depdikbud. (1997). Organisasi pelaksanaan sistem ganda. Jakarta : Direktorat Pendidikan Menengah Kejuruan

Departemen Pendidikan Nasional. (2006). Panduan kurikulum tingkat satuan pendidikan. Jakarta: Direktorat Pendidikan Menengah Kejuruan.

Depdikbud. (1997), Organisasi pelaksanaan sistem ganda, Jakarta. Direktorat Pendidikan Menengah Kejuruan.
(2006). Kurikulum Edisi 2006. Jakarta: Direktorat Pendidikan Menengah Kejuruan.

Donaldson Les \& Scanell, Edward E. (1993). Pengembangan sumber daya manusia panduan bagi pelatih pemula. Jakarta: Gaya Media Pratama.

H.J.X Fernanders. (1984). Evaluation of Educational Program. Jakarta : National Education Plannging, Eval \& Curicullum.

Helmut Nolker. (1983) Pendidikan kejuruan. Jakarta: Gramedia.

Majelis Pendidikan Kejuruan Nasional. (1996). Konsep Pendidikan Sistem Ganda. Jakarta

Pasavec, E.J \& Carry, R.G. (1985). Program evaluation, methods and case studies. Englewood Cliff: Prentice Hall. Inc.

Rainer. (1992). Vocational training in the dual system. Hamburg: Hamburg Institute.

Stufflebeam, D. L Shinkield, A.J. (1985). Systematic Evaluation. Massauchusetts: Kulner Academic Publisers Group Distribution Centre.

Sudjana. (1992). Metode statistika. Bandung : Tarsito.

Sugiyono. (2002). Metode penelitian administrasi, Bandung : Alfabeta

Wardiman Djojonegoro. (1999). Pengembangan sumber daya manusia. Jakarta : Balai Pustaka Pesero.

Worthen, B.R. and Sander, J.R. (1973). Education evaluation, theory andpractice. Washington: Charles a Jones Publishing Company. 